\title{
FACTORS DETERMINING BRAND RESONANCE OF APPLE IPHONE
}

\author{
V.Anupriya ${ }^{1}$, Dr.G.S.Maheswari ${ }^{2}$, Dr.M.Kavitha ${ }^{3}$ \\ ${ }^{1}$ Research scholar, Department of Commerce, Vels Institute of Science, technology and advanced studies, Pallavaram, Chennai \\ ${ }^{2}$ Professor \& Research Supervisor, Department of Commerce, Vels Institute of Science, technology and advanced studies, \\ Pallavaram, Chennai \\ ${ }^{3}$ Professor \& Research Supervisor, Department of Commerce, Vels Institute of Science, technology and advanced studies, \\ Pallavaram, Chennai
}

\section{INTRODUCTION}

Building brand resonance in a competitive market can play an active role in the modern marketing arena. It is now widely acknowledged by companies and business enterprises that strong brand resonance will create a competitive advantage in the marketplace that will enhance their overall reputation and credibility.Brand resonance depends on a systematic understanding of the company's consumers, competitors, and marketing environment. Brand resonance is based on appropriate identity that needs to reflect the marketing strategy and the firm's willingness to invest in the programs needed for the brand to live up to its promise as well as commitment to consumers. Strong brands take pleasure in consumer loyalty, the possibility to charge premium prices, and extensive brand power to hold up new product and service launches. Companies and business enterprises need to have careful as well as systematic understanding of consumer beliefs, behaviors, product or service characteristics as well as attributes and rivals. The continuous technological innovation creates a competitive scenario where brand loyalty is nullified with the uninterrupted inflow of competitive product varieties and models and the brand resonance effect in terms of relationship that a consumer has with the product and the extent to which consumers feel that they are in ,synce with the brand gets alleviated. Brand resonance refers to the nature of heightened brand-centric relationships and is characterized by intense psychological attachment with a brand as well as active, volitional behavior directed toward the brand's benefit.Mobile Users are very interested and eager to purchase Applei phone. This research is analysed the customer perception towards applei phone.

\section{REVIEW OF LITERATURE}

Wasip bin latif et al(2014) Building Brand Resonance in a Competitive Environment: A Conceptual Model.Advances in Environmental Biology, 8(9) Special 2014, Pages: 593-600. Based on a comprehensive review of several earlier works, here we propose a plausible framework for building brand resonance in sequential order, namely, awareness of the brand, association of the brand, superiority of the brand, affection of the brand and brand loyalty. We suggest that these activities could play an important role in creating brand resonance among consumers. As a whole, based on the existing literatures, we have tried to provide a comprehensive view on the imperative components of brand resonance for building brand resonance in a competitive market.

UmeshRamchandraRaut(2016) Implication of brand resonance model to construct the relationship in retail: conceptual approach. IJMRR. Vol 6. Issue 2. The objectives of development of relationship between customers and retail store, first retailers need to understand the importance of many factors, which influence relationship between customers and stores such as awareness, performance, image, judgment and feelings. With the help present study we can say that, implementation of store loyalty programs is not only the best way to gain a loyalty and not always this loyalty will transform in to strong relationship between customers and stores.

VishagBadrinarayanan(2016) Brand resonance in franchising relationships: A franchisee-based perspective. Journal of Business Research 69 (2016) 3943-3950. The formation of brand-centric relationships between franchisors and franchisees is of utmost importance to the success of franchising endeavors. This study offers a parsimonious framework of the antecedents of brand resonance in franchising relationships and test hypothesized relationships from the franchisee's perspective using data collected from business format franchisees in South Korea. Results demonstrate that franchisor's knowledge specificity, franchisor's trade equity, and franchisee's trust in franchisors are instrumental in the formation of brand resonance. Implications for researchers and practitioners as well as directions for future research are offered

Amit K. Sinha(2017) Impact of Product Innovation in Building Brand Equity on Consumer"s Choice with a Focus on Brand 
Resonance. International Journal of Innovation, Management and Technology, Vol. 8, No. 6, December 2017. Customer-Based Brand Equity Pyramid developed by Keller under two major components i.e. emotional and rational route to brand relationship building to make strong connections between the consumer and the brand and which characterizes the brand resonance. The methodology applied for the research was primarily based on scale development of the independent and dependent variables. The probability factor in dependent value was more appropriate for logistic regression to test the hypotheses. The findings of the research contributed to the theory of brand resonance in relation to innovation strategy for the product categories where the deciding factor of the success is to adapt the technology within competitive innovation framework in a given time period.

Kavitha M, (June/2017)A Study Of Customer Perception Of Youth Towards Branded Fashion Apparels In Chennai City.International Journal of Applied Business and Economic Research, Vol.15 (2017). ISSN : 0972-7302. The main purpose of this paper is to study \& analyze the brand preference of youth in buying branded apparels in Chennai city and to find the factors which influence the buying behavior of youth for branded apparels. The researcher applied simple random sampling method collect 500 respondents from different customers. This research finds that the customer of youth gets more satisfaction and convenient when they use the branded apparels. The only reason to attract this is branded stores are offering exclusive apparels with good quality and reasonable price.

Kavitha M, (Sep/2017) Factors Influencing Employee's Job Satisfaction - An Empirical Study Among Employees of IT Sectors in Chennai City..International Journal of Applied Business and Economic Research, Vol.15 (2017). ISSN : 09727302. The main aim of this study is to identify the perceptual difference of Employees with respect to the job satisfaction of the firm and to find out the factors determining Job Satisfaction of employees in the firm. Finally, To measure the impact of job satisfaction of employees. The researcher used Simple random sampling technique has been used for analysis. Sample size of the study consists of 100 respondents. The results shows that monetary factors of salary and Non-monetary factor training and development influenced employees to get job satisfaction. Finally it concludes that job satisfaction is the main factor to increased wealth of the firm and to feel happiness to the employees.

Kavitha M, (Sep/2018)A Study On Customer Experience In E-Tailing And Retailing. Indian Journal of Public Health Research and Development.Vol:9,No.9,Sep 2018. ISSN : 09760245. The purpose of this paper is to explore the relationships between the various determinants and customer experience in the retail and e-tail markets which is widely seen in the Indian market place. The results included in this research about the demographic variables and the determinants of customer experience are focused on hyper and retail markets respectively. This paper provides retailers with specific knowledge of the determinants that the customer considers being most important and significant contributor to an enhanced customer experience.

Kavitha M, (Sep/2018) Effectiveness of Social media marketing. Indian Journal of Public Health Research and Development. Vol:9,No.11,Nov 2018. ISSN : 0976-0245. The main aim of this study is to know about the demographic profile of the customers of social media marketing and to analyse the effects of various forms of social media marketing on the firm's sales and other activities. The researcher used regression analysis, percentage analysis to find the result. It finds that the firms are achieved their target because of social media marketing. The firm's products are reached in all levels of customers through social media.Finally, it concludes that, Companies should create innovative customer experiences and specific strategies for media to identify the best path for driving up social media marketing performance.

Kavitha M, (Jan/2019) A Study On Customer preferences on Green Marketing. Indian Journal of Public Health Research and Development. Vol:10,No.1,Jan 2019. ISSN : 0976-0245. In this research paper mainemphasis significance of Green Marketing in developing countries, factor comparison with the actual trend and sustainable impact on the marketing procedure of the dynamic society. Customer satisfaction level and the 
industrial presence to make a move towards the dynamic changes is measurd. It explores how to market the green marketing strategy in depth. The paper describes the current scenario highlight the Green Marketing challenges in Indian Market.

Kavitha M, (Jan/2019) Green Marketing in food Industry and It's Impact on Health Issues. Indian Journal of Public Health Research and Development. Vol:11,No.1,OCT 2019. ISSN : 0976-0245. The main aim of this study is analyse the green marketing in food industry and its impact on health issues ofconsumers. The researcher used one way anova to find the result. There is a negative relationship between green foods and health issues. The consumers used green foods the feel there is no health issues and vice-versa. Finally, it concludes that most of the consumers are using organic/green foods for avoid the health issues.

UmeshRamchandraRaut et al(2019) Analysis of Brand Resonance Measures to Access, Dimensionality, Reliability and Validity. International Management Institute. The aim of the present study is to analyse. brand resonance measures to assess reliability, dimensionality and validity using existing models of brand resonance. This study initiated scale extraction and operationalization processes for 72 observed variables to measure nine latent variables and obtained 34 statistically extracted observed variables. The study provides a reliable and validated means to measure brand resonance constructs. The study develops a brand resonance scale, which can help brand managers to measure consumers' levels of brand resonance, in order to describe the strength of the bond of their consumer with their brand(s). This study develops empirically extracted measures of brand resonance, making it distinctive in the branding literature. The study also ensures all important aspects of measurement scale, such as validity and reliability.

\section{OBJECTIVES OF THE STUDY}

To study the customer perception towards applei phone

To find the factors determining brand resonance of applei phone

\section{HYPOTHESES OF THE STUDY}

There is no significant difference among the customer perception towards applei phone

There is no significant influence among the factors determining brand resonance of applei phone

\section{ANALYSIS AND DISCUSSION}

In this research the researcher finds the brand resonance and customer perception towards apple iphone. To find the perception of customers the researcher used frequency analysis. The results are shown below

\begin{tabular}{|r|l|r|r|r|r|}
\hline \multicolumn{7}{|c|}{ Table-1 Gender } \\
\hline \multicolumn{2}{|c|}{} & $\begin{array}{r}\text { Frequenc } \\
\text { y }\end{array}$ & Percent & $\begin{array}{c}\text { Valid } \\
\text { Percent }\end{array}$ & $\begin{array}{c}\text { Cumulative } \\
\text { Percent }\end{array}$ \\
\hline \multirow{3}{*}{ Valid } & Male & 316 & 63.2 & 63.2 & 63.2 \\
\cline { 2 - 6 } & Female & 184 & 36.8 & 36.8 & 100.0 \\
\cline { 2 - 6 } & Total & 500 & 100.0 & 100.0 & \\
\hline \multicolumn{7}{|c|}{ Source-Computed data } \\
\hline
\end{tabular}

The above table shows that $63.2 \%$ of male customers and $36.8 \%$ of female customers are interested to purchase apple iphone. The sample size dominates by male customers.

\begin{tabular}{|c|l|r|r|r|r|}
\hline \multicolumn{7}{|c|}{ Table - 2 } & \multicolumn{3}{c|}{ Educational Qualification } \\
\hline \multicolumn{2}{|c|}{} & $\begin{array}{c}\text { Frequenc } \\
\text { y }\end{array}$ & Percent & $\begin{array}{c}\text { Valid } \\
\text { Percent }\end{array}$ & $\begin{array}{c}\text { Cumulative } \\
\text { Percent }\end{array}$ \\
\hline \multirow{3}{*}{ Valid } & School level & 146 & 29.2 & 29.2 & 29.2 \\
\cline { 2 - 6 } & U.G & 126 & 25.2 & 25.2 & 54.4 \\
\cline { 2 - 6 } & P.G & 116 & 23.2 & 23.2 & 77.6 \\
\hline
\end{tabular}




\begin{tabular}{|l|l|r|r|r|r|}
\hline & Professionals & 112 & 22.4 & 22.4 & 100.0 \\
\cline { 2 - 5 } & Total & 500 & 100.0 & 100.0 & \\
\hline
\end{tabular}

Source-Computed data

It was presented in the above table $29.2 \%$ of school level customers, $25.2 \%$ of Under graduate customers, $23.2 \%$ of PG customers and $22.4 \%$ of professional are interested to buy apple iphone.

\begin{tabular}{|r|l|r|r|r|r|}
\hline \multicolumn{2}{|c}{ Table - 3 } & \multicolumn{2}{c|}{ Awareness of service } \\
\hline \multicolumn{2}{|c|}{} & $\begin{array}{c}\text { Frequenc } \\
\text { y }\end{array}$ & Percent & $\begin{array}{c}\text { Valid } \\
\text { Percent }\end{array}$ & $\begin{array}{c}\text { Cumulative } \\
\text { Percent }\end{array}$ \\
\hline \multirow{3}{*}{ Valid } & Yes & 321 & 64.2 & 64.2 & 64.2 \\
\cline { 2 - 6 } & No & 179 & 35.8 & 35.8 & 100.0 \\
\cline { 2 - 6 } & Total & 500 & 100.0 & 100.0 & \\
\hline \multicolumn{6}{|c|}{ Source-Computed data } \\
\end{tabular}

It indicate in the above table $64.2 \%$ of customers are getting awareness about the apple iphone and $35.8 \%$ of customers are not getting awareness about the apple iphone.

The customer perception consist of six variables and it subsequent influence over brand resonance is measured through linear multiple regression analysis. The results are presented below

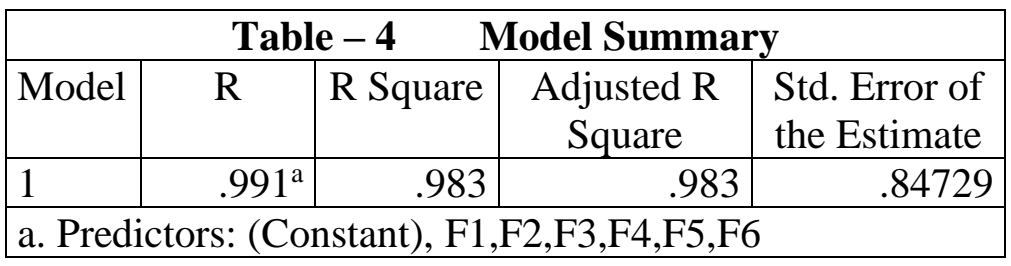

Source-Computed data

From the above table it is found that $\mathrm{R}=.991 \mathrm{R}$ square $=.983$ and adjusted $\mathrm{R}$ square .983 . This implies the customer perception variable create $98 \%$ variance over the brand resonance. The cumulative influence of six variables of customer perception over brand resonance is ascertained through the following one way analysis of variance.

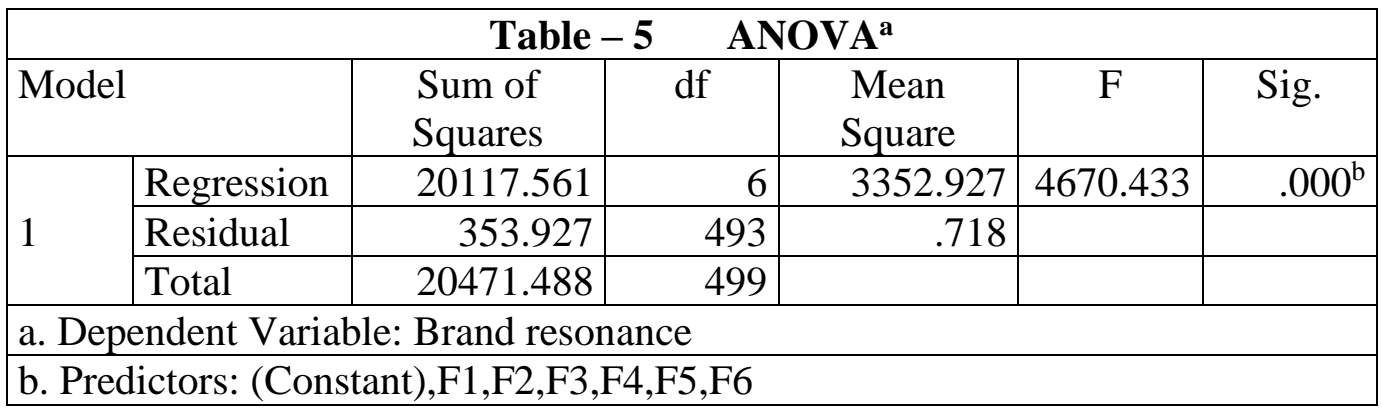

Source-Computed data

Table 5 presents that $\mathrm{f}=4670.433 \mathrm{p}=.000$ are statistically significant at $5 \%$ level. This indicates all the six variables cumulatively responsible for brand resonance. The individual influence of all this six variables is clearly presented in the following co-efficient table.

\section{Table - 6 Coefficients ${ }^{\mathrm{a}}$}




\begin{tabular}{|c|c|c|c|c|c|c|}
\hline \multirow{2}{*}{\multicolumn{2}{|c|}{ Model }} & \multicolumn{2}{|c|}{$\begin{array}{l}\text { Unstandardized } \\
\text { Coefficients }\end{array}$} & \multirow{2}{*}{$\begin{array}{c}\text { Standardized } \\
\text { Coefficients } \\
\text { Beta }\end{array}$} & \multirow[t]{2}{*}{$\mathrm{t}$} & \multirow[t]{2}{*}{ Sig. } \\
\hline & & B & Std. Error & & & \\
\hline \multirow{7}{*}{1} & $($ Constant $)$ & .146 & .134 & & 1.094 & .275 \\
\hline & $\begin{array}{l}\text { Brand } \\
\text { Loyalty }\end{array}$ & 1.323 & .111 & .268 & 11.904 & .000 \\
\hline & $\begin{array}{l}\text { Expected } \\
\text { Features }\end{array}$ & 1.079 & .121 & .242 & 8.882 & .000 \\
\hline & $\begin{array}{l}\text { High } \\
\text { technology }\end{array}$ & .284 & .158 & .054 & 1.803 & .072 \\
\hline & $\begin{array}{l}\text { Customer } \\
\text { satisfaction }\end{array}$ & .575 & .138 & .116 & 4.181 & .000 \\
\hline & Status & 1.551 & .153 & .320 & 10.169 & .000 \\
\hline & Quality & 1.067 & .156 & .013 & 5.427 & .000 \\
\hline
\end{tabular}

Source-Computed data

From the above table it shows that Brand Loyalty (Beta=.268, $\mathrm{t}=11.904, \quad \mathrm{p}=.000)$, Expected Features $(\mathrm{Beta}=.242, \mathrm{t}=8.882, \mathrm{p}=.000), \quad$ High technology $\quad($ Beta $=.054, \quad \mathrm{t}=1.803, \mathrm{p}=.072)$, Customer satisfaction(Beta $=.116, \quad \mathrm{t}=4.181$, $\mathrm{p}=.000)$, Status $($ Beta $=.320, \mathrm{t}=10.169, \mathrm{p}=.000)$ and Quality(Beta=.013, t=.427, $\mathrm{p}=.000)$ are statistically significant at $5 \%$ level. This indicates that the customers are very much interested the apple iphone are brand loyalty and status.

\section{FINDINGS ABD CONCLUSIONS}

Apple Inc is the most valuable company in the history of the world. Apple Inc created a lot of revolutionary products like Macintosh, iPod, iPhone, iPad, and Apple watch. Nowadays apple iphone is the fast moving mobile product. The researcher finds the customer perception and brand resonance of applei products.

The customers are preferred the apple iphone for various reasons. There are brand loyalty, high technology, good features, quality, and status and customer satisfaction. The most attracted variables are status and brand loyalty. This will create the brand resonance to the concern products. Finally, it concludes that the customers are admired by attractive features and they feel the price is more compared with other branded products. The marketers are produced the products in future with affordable price which will be used by lower income group also.

\section{REFERENCES}

1. Amit K. Sinha (2017) Impact of Product Innovation in Building Brand Equity on Consumeres Choice with a Focus on Brand Resonance. International Journal of Innovation, Management and Technology, Vol. 8, No. 6, December 2017.

2. Kavitha M, (June/2017)A Study Of Customer Perception Of Youth Towards Branded Fashion Apparels In Chennai City.International Journal of Applied Business and Economic Research, Vol.15 (2017). ISSN : 0972-7302.

3. Dr. D.Paul Dhinakaran, "Exports and Imports Stagnation in India During Covid-19- A Review” GIS Business (ISSN: 1430-3663 Vol15-Issue-4-April-2020).

4. Kavitha M, (Sep/2017) Factors Influencing Employee's Job Satisfaction - An Empirical Study Among Employees of IT Sectors in Chennai City...International Journal of Applied Business and Economic Research, Vol.15 (2017). ISSN : 0972-7302.

5. Kavitha M, (Sep/2018)A Study On Customer Experience In E-Tailing And Retailing. Indian Journal of Public Health Research and 
Development.Vol:9,No.9,Sep 2018. ISSN : 0976-0245.

6. Kavitha M, (Sep/2018) Effectiveness of Social media marketing. Indian Journal of Public Health Research and Development. Vol:9,No.11,Nov 2018. ISSN : 0976-0245.

7. Kavitha M, (Jan/2019) A Study On Customer preferences on Green Marketing. Indian Journal of Public Health Research and Development. Vol:10,No.1,Jan 2019. ISSN : 0976-0245.

8. Kavitha M, (Jan/2019) Green Marketing in food Industry and It's Impact on Health Issues. Indian Journal of Public Health Research and Development. Vol:11,No.1,OCT 2019. ISSN : 0976-0245.

9. UmeshRamchandraRaut et al(2019) Analysis of Brand Resonance Measures to Access,
Dimensionality, Reliability and Validity. International Management Institute.

10. UmeshRamchandraRaut(2016) Implication of brand resonance model to construct the relationship in retail: conceptual approach. IJMRR. Vol 6. Issue 2.

11. VishagBadrinarayanan(2016) Brand resonance in franchising relationships: A franchisee-based perspective. Journal of Business Research 69 (2016) 3943-3950.

12. Wasip bin latif et al(2014) Building Brand Resonance in a Competitive Environment: A Conceptual Model.Advances in Environmental Biology, 8(9) Special 2014, Pages: 593-600. 